\title{
二次元チャンネル流における逆遷移過程で観察される擋乱について
}

\section{Disturbance observed in laminarization of two dimension channel flow}

\author{
○沼野貴之 (信州大院) 正 松原雅春 (信州大)
}

Takayuki Numano, Shinsyu University, 4-17-1 Wakasato, Nagano-shi 380-8553

Masaharu Matsubara, Shinsyu University 4-17-1 Wakasato, Nagano-shi 380-8553 5

Key Words: disturbance, laminarization, two dimension channel flow

\section{1 はじめに}

あるレイノルズ数以下の流れにおいて強い擋乱を挿入し流れ を乱しても乱流を維持することができず層流へと遷移する。こ の限界レイノルズ数付近では一般的に遷移のスピードが緩やか で遷移過程において擋乱構造を確認することができることが知 られている(1)(2).

二次元チャンネル流において，代表長さをチャンネル幅，代 表速度を平均流速と置いたとき, 擋乱を与えなくても流れが乱 流へと遷移する臨界レイノルズ数は線形安定性理論より 7696 になり,このレイノルズ数以下であっても強い擋乱を挿入する ことにより乱流を発達させ維持することが可能である. Badri $\operatorname{Narayanan}^{(1)}$ らは再層流化現象の起こるときのレイノルズ数を レイノルズ応力の減衰を外抻して求め, その值を $1865 \pm 65$ と 決定している. Carlson ${ }^{(3)}$ らは実験により，人工的に擋乱を挿 入し, 擋乱構造がレイノルズ数 1330 以下のとき擋乱が維持で きず減衰していくことを示している. 奥村 ${ }^{(4)}$ らはスパン幅を 应大させることでレイノルズ数を下げることで流れを乱流から 層流へと遷移させ，流れの可視化による観察で限界レイノルズ 数を 1500 付近とし, 乱流の流れの中に乱流の特徽的構造とは 異なる大きなスケール構造が現れだす $R e=2300$ 付近を重要 な臨界值のひとつとしてあげている。

本研究では奥村らと同様にスパン幅を拡大させることで乱流 から層流へと遷移させるチャンネル流を用いる. ただしチャンネ ル試験部長さを奥村らの $2000 \mathrm{~mm}$ から $3500 \mathrm{~mm}$ にし, チャン ネル幅を変更できるような実験装置を製作し実験を行った。こ れにより逆遷移の過程を流れ方向にさらに追うことが可能とな り，またチャンネル幅を大きくすることにより，擋乱の構造が 相対的に大きくなると考えられ，チャンネル幅が小さいときに 比べて低い流速で同レイノルズ数にすることができるため，再 層流過程で見られる擋乱構造を調べるには有利である。この実 験装置を用いて可視化実験を行い, 奥村らが得た実験結果と比 較し，再層流遷移過程で見られる摚乱構造の特徴，性質につい て考察する.

\section{2 実験装置及び実験方法}

実験装置の概要を Fig1 に示す. 装置は回流式でポンプ, ノ ズル, 助走区間, 拡大部, 試験部, 流出口により構成されてい る. 流れはポンプによって加圧され, 絞り比 18 を持つノズル によって絞られ, 長さ $1600 \mathrm{~mm}$, チャンネル幅 $10 \mathrm{~mm}$, ス パン幅 $500 \mathrm{~mm}$ の助走区間へと入る. ノズル出ロから流れ方 向に $100 \mathrm{~mm}$ 各壁から $1 \mathrm{~mm}$ の位置に, 直径 $0.5 \mathrm{~mm}$ のト リッピングワイヤーを初期擋乱として取り付けており，流れを 乱し助走区間で十分に発達した乱流となる. 次に, 流れは長さ $1400 \mathrm{~mm}$ スパン幅が入り口で $500 \mathrm{~mm}$ (アスペクト比 50) から 出口で $600 \mathrm{~mm}$ (アスペクト比 60 ) になる拡大部へと入る. 拡大 部では剥離を起こさないように広がり角を約 $2 \circ$ になるように 設計してある.ここでレイノルズ数はチャンネル上流部に対し て 0.83 倍になる.そして流れは長さ $3500 \mathrm{~mm}$ の試験部へと流
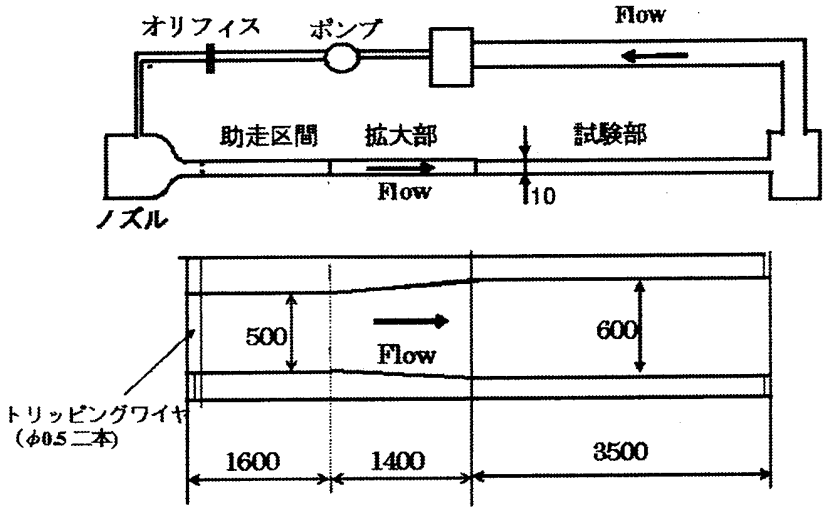

Fig. 1: Outline of experimental apparatus.

入する. そして試験部から流出口に流れ出し, ポンプへと戻る. ポンプの下流には直径 $40 \mathrm{~mm}$ のパイプに対し, 直径 $30 \mathrm{~mm}$ の 口径のオリフィスが取り付けられており, オリフィス上流 $35 \mathrm{~mm}$ の位置とオリフィス下流 $45 \mathrm{~mm}$ と $55 \mathrm{~mm}$ の位置より圧力が取 り出せるようになっている. 以下の式 ${ }^{(5)}$ を用いてオリフィス の上流と下流 $45 \mathrm{~mm}$ の差圧 $\Delta P$ より流量 $V$ を求め, 試験部の レイノルズ数 $R e$ を決定した.

$$
\begin{gathered}
V=C A_{0} \sqrt{\frac{2 \Delta P}{\rho}} \\
C=0.597-0.011\left(\frac{A_{0}}{A_{1}}\right)+0.432\left(\frac{A_{0}}{A_{1}}\right)^{2}
\end{gathered}
$$

ここで $A_{0}$ はオリフィス断面積, $A_{1}$ はパイプ断面積, $\rho$ は密 度である.さらにオリフィス下流のそれぞれにおける上流との 差圧と試験部におけるレイノルズ数の関係を Fig2 に示す.下 流 $45 \mathrm{~mm}$ と下流 $55 \mathrm{~mm}$ における差圧には 1 割程度の誤差が生 じている.このことから圧力取り出し位置による圧力差からレ イノルズ数は \pm 100 程度の誤差があると考えられる.

可視化実験には有効画素数 $659(H) \times 494(V)$ の CCD 力 メラ $(X C L-V 500)$ を用い, シャッタースピード 1/250(s), フレームレート $1 / 60(\mathrm{~s})$ の条件の下で撮影する. 試験部入り口 から下流に $3300 \mathrm{~mm}$ の流れの撮影を行った. 試験部入り口か ら撮影位置までの距離を $L$ とし，チャンネル幅を $D$ とした時, $L / D=330$ である. 光源には八ロゲンランプを用い, カメラ の左右からそれぞれ斜め方向に照射する。トレーサ一粒子には 流れのせん断面に平行に配光し, 光を反射させやすい薄片状の パール顔料を（7〜8 $\mu \mathrm{m}$, 比重 3.1）を用いた.このトレーサー 粒子はせん断が働く面に平行に向くため, 可視化のときに縞状 になる部分はせん断面が同じ方向を向いている領域を表す.

\section{3 実験結果及び考察}

Fig3 は $R e=2700$ における可視化写真である. 流れ方向は 写真の左から右である. Fig3 では流れ方向に $15 \sim 25 \mathrm{~mm}$ スパ 


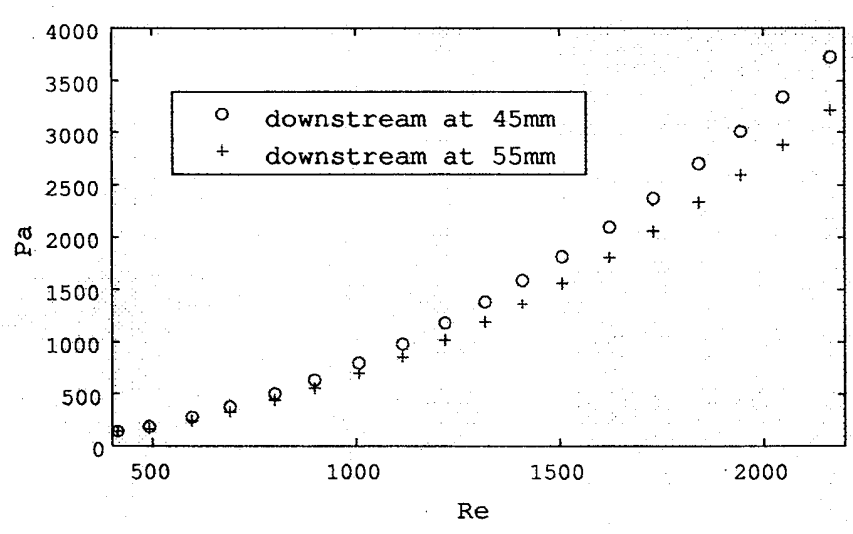

Fig. 2: Contrast between Re and differential pressure.

ン方向に $7 \mathrm{~mm}$ 程度のスケールを持つ形状の不均一なスケール の小さい擋乱構造が流れの全体を占めている. この擋乱構造を時 間ごとに追うと発生と消滅を繰り返しながら流れている. Fig4 は $R e=2200$ における可視化写真である. $R e=2700$ のとき にスケールの小さい擋乱構造が流れの全体を占めているのに対 し，流れ方向に長い縞状構造がパッチ状に見られる. 縞状構造の パッチの流れ方向とスパン方向の広がりはどちらも $300 \mathrm{~mm}$ 程 度でこのパッチは時間とともに流れ方向に移動している. Fig5 は $R e=1700$ における可視化写真である. このとき縞状構造の 占める割合とスケールの小さい擋乱構造の占める割合が逆転し， スケールの小さい擋乱構造がパッチ状になって見られる.この ときの確認されたパッチの流れ方向とスパン方向の広がりはと もに $300 \mathrm{~mm}$ 程度である. Fig6 は $R e=1400$ における可視化 写真である.このとき縞状構造と層流状態が流れの大部分を占 め, スケールの小さな擋乱からなるパッチが局所的に見られた. Fig7 は $R e=1300$ における可視化写真である. 光の反射が一 様で特徵的構造が見られず，完全な層流状態になったと考えら れる.

本実験で $R e=2700$ のときに観察した擋乱構造と奥村らが $R e=2680$ で観察した擋乱構造の特徵は似ており, チャンネル 幅で無次元化した擋乱のスパン方向スケールが約 0.7 となり奥 村らとほぼ一致している. 本実験の $R e=2200$ のとき奥村ら の $R e=2130$ 同様にスケールの小さい摚乱の領域内に流れ方向 に長い編状構造を確認し，構造のチャンネル幅で無次元化した スパン方向スケールは大きいもので 1 程度であり，奥村らが観 察した縞構造のスパン方向スケール同程度である. また本実験 の $R e=1700$ のとき, 奥村らの $R e=1660$ のときと同様にス ケールの小さな擋乱構造と編状構造の占める割合が逆転し, ス ケールの小さい構造がパッチ状に確認されている.

チャンネル幅を変化させてもレイノルズ数に対するそれぞれ の擋乱構造の占める割合は奥村らが得た結果とほぼ同様で，遷 移過程で確認された摚乱構造のスケールはどれもチャンネル幅 で無次元化したらほぼ等しくなった．奥村らの試験部における レイノルズ数が助走区間に対して 0.73 倍なのに対し，本実験装 㯰は 0.83 倍とレイノルズ数の変化の割合が小さくなっている. しかし実験結果を比較したとき， $L / D$ がほぼ同じ位置での流れ が同様の特徵が現れていることから，逆遷移においてレイノル ズ数の変化の大きさは，要移過程に対して影響を与えていない と考えられる。

\section{4 おわりに}

可視化実験により再層流遷移過程は段階的に起こり, レイノ ルズ数に対してそれぞれ現れる擋乱構造や，それらの占める割 合は奥村らが得た結果と上流と下流のレイノルズ数比を変化さ せてもほぼ同様であった.

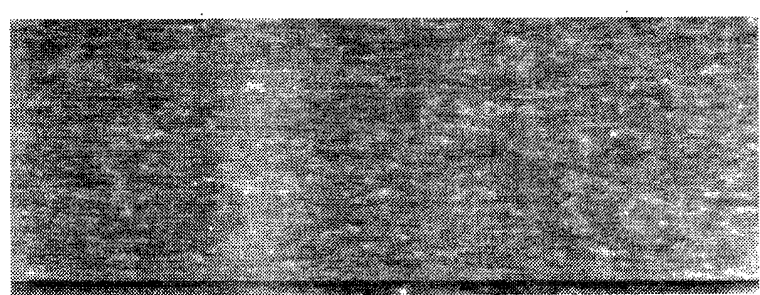

Fig. 3: Flow visualization $\mathrm{Re}=2800$.

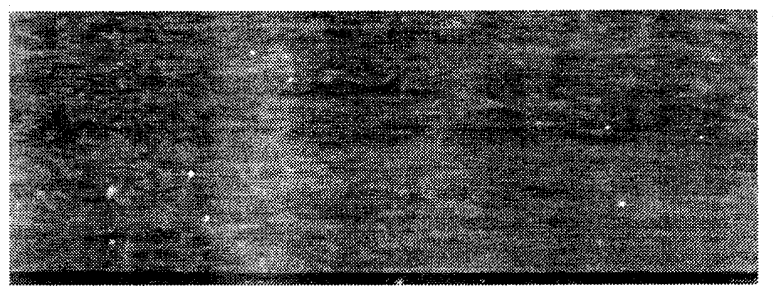

Fig. 4: Flow visualization $\mathrm{Re}=2200$.

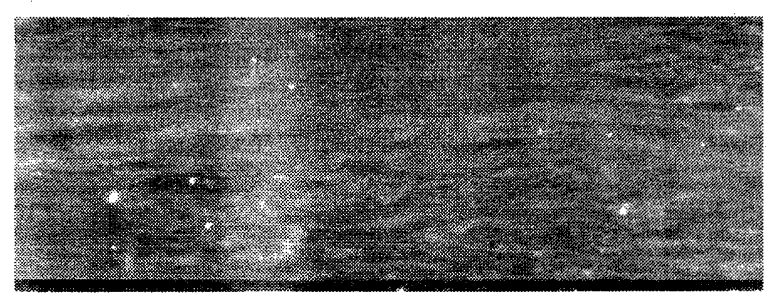

Fig. 5: Flow visualization $\operatorname{Re}=1700$.

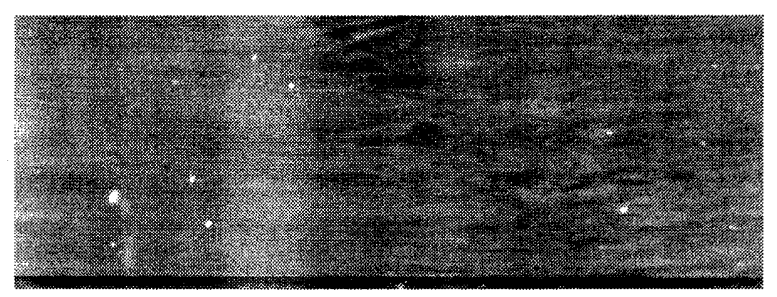

Fig. 6: Flow visualization $\operatorname{Re}=1400$.

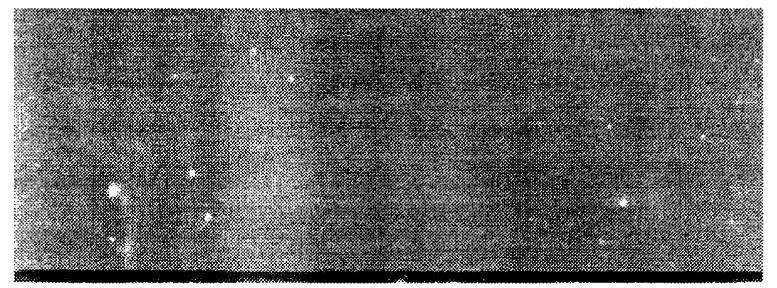

Fig. 7: Flow visualization $\mathrm{Re}=1300$.

\section{References}

[1] M.A.Barid Narayanan : J.Fluid Mech.,31(1968)609-623.

[2] J.Peixinho and T.Mullin : Phys Rev Lett.96,094501 (2006).

[3] D.R.Carlson et al : J.Fluid Mech.,121(1982)133-166.

[4] 奥村雄志, 松原雅春 : 日本流体力学会年会 2006

[5] 日本工業標準調查会 : JIS8762, 円形管路の絞り機構による 流量測定方法 